
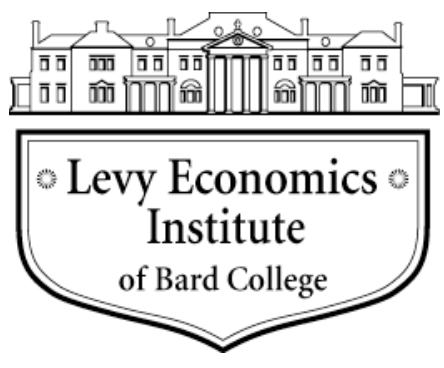

Working Paper No. 732

\title{
Beyond Full Employment: \\ The Employer of Last Resort as an Institution for Change
}

by

\author{
Pavlina R. Tcherneva \\ Levy Economics Institute of Bard College
}

September 2012

The Levy Economics Institute Working Paper Collection presents research in progress by Levy Institute scholars and conference participants. The purpose of the series is to disseminate ideas to and elicit comments from academics and professionals.

Levy Economics Institute of Bard College, founded in 1986, is a nonprofit, nonpartisan, independently funded research organization devoted to public service. Through scholarship and economic research it generates viable, effective public policy responses to important economic problems that profoundly affect the quality of life in the United States and abroad.

Levy Economics Institute P.O. Box 5000

Annandale-on-Hudson, NY 12504-5000

http://www.levyinstitute.org

Copyright (C Levy Economics Institute 2012 All rights reserved

ISSN 1547-366X 


\begin{abstract}
Over the past decade and a half the ability of the employer-of-last-resort (ELR) proposal to deliver full employment and price stability has been discussed at length in the literature. A different issue has received relatively little attention-namely, the concern that even when the ELR produces these macroeconomic benefits, it does so by offering "low-paying" "dead-end" jobs, further denigrating the unemployed. In this context, the important buffer stock feature of the ELR is misconstrued as a hydraulic mechanism that prioritizes macroeconomic stability over the program's benefits to the unemployed.
\end{abstract}

This paper argues that the two objectives are not mutually exclusive by revisiting Argentina's experience with Plan Jefes and its subsequent reform. Plan Jefes is the only direct job creation program in the world specifically modeled after the modern ELR proposal developed in the United States. With respect to macroeconomic stability, the paper reviews how it exhibits some of the key stabilizing features of ELR that have been postulated in the literature, even though it was not designed as an unconditional job guarantee. Plan Jefes also illustrated that public employment programs can have a transformative impact on persistent socioeconomic problems such as poverty and gender disparity. Women—by far the largest group of program beneficiaries-report key benefits to their communities, families, children, and (importantly) themselves from participation in Jefes.

Argentina's experience shows that direct job creation programs that offer employment at a base wage can have the unique capacity to empower and undermine prevailing structures that produce and reproduce poverty and gender disparities. Because the latter two problems are multidimensional, the ELR cannot be treated as a panacea, but rather as an important policy tool that remedies some of the most entrenched and resilient causes of poverty and gender inequality. The paper examines survey evidence based on narratives by female participants in Jefes to assess these potentially transformative aspects of the ELR proposal.

Keywords: Employer of Last Resort; Full Employment; Gender Inequality; Poverty JEL Classifications: D63, E6, E24, I3 
At a time when the unemployment problem seems to be particularly intractable, it is useful to revisit the one policy proposal that promises to eliminate it altogether-namely, the employer of last resort (ELR). The present paper examines the only real-world program for direct job creation that was specifically modeled after the modern ELR proposal developed in the United States (Kostzer 2008). This is Argnetina's Plan Jefes y Jefas de Hogares (Jefes or Plan Jefes hereafter), which was launched after the 2001 financial meltdown to deal with the devastating economic fallout. Plan Jefes offered a voluntary job opportunity to unemployed heads of households in a community project and was federally funded but locally administered. The program design did not conform completely to the ELR proposal, but nevertheless exhibited important institutional features that will be examined here. The first task is to assess whether Plan Jefes provided the macroeconomic stabilization effects that advocates attribute to the ELR program. The second is to evaluate how ELR programs can be designed to do more than just deal with the problems of economic instability and unemployment. Though not by design, Plan Jefes illustrated that public employment programs can have a transformative impact on persistent socioeconomic problems such as poverty and gender disparity. Because the latter two problems are multidimensional, the ELR cannot be treated as a panacea, but should be seen instead as an important policy tool that remedies some of the most entrenched and resilient causes of poverty and gender inequality.

\section{WHAT IS THE EMPLOYER OF LAST RESORT PROGRAM?}

The employer of last resort (ELR) is a proposal for a federally-funded program in which the government employs all of the jobless who are ready, willing, and able to work in a public sector project at a base wage. The proposal stems from the Post Keynesian understanding that unemployment is a monetary phenomenon and that profit-driven capitalist economies consistently fail to produce and maintain anything close to true full employment. Keynes himself had argued that governments must do everything that is humanly possible to produce "a reduction of the unemployed to the sort of levels we are experiencing in wartime...that is to say, an unemployed level of less than 1 per cent unemployed" (Keynes 1980: 303). This tight definition of full employment is at the heart of the ELR proposal. Calls for the government to become the employer of last resort were popular as early as the 1930s (Kaboub 2007), but contemporary scholarship has formalized the proposal as follows. 


\section{ELR Offers an Infinitely Elastic Demand for Labor}

ELR is not a depression solution. There are people looking for work even in expansions and this permanent and voluntary program hires the unemployed irrespective of the phase of the business cycle (Tcherneva 2012). Since the federal government is the only institution that can divorce the profitability of hiring from the decision to hire, the program would eliminate unemployment by taking workers "as they are" regardless of their work experience, race, age, or gender (Minsky 1986, Wray 1998).

\section{ELR Hires off the Bottom}

Unemployment is eliminated by direct job creation, not by "pump priming" or by raising aggregate demand. It is a bottom-up approach to policy that offers an employment safety-net to those individuals who tend to be hired last and fired first from private sector work-normally the least skilled and least educated (Tcherneva 2012). By contrast, pro-growth pro-investment aggregate demand policies always increase demand for the highly skilled, highly educated, and highly paid workers first (Tcherneva 2011a). Once the economy begins to recover, demand starts to trickle down to other workers, but never far enough to reach all of those who wish to work. Instead of targeting some level of investment or output growth (which may or may not produce true full employment), the ELR program goes to the heart of the problem and closes the demand gap for labor by guaranteeing a job at a base wage (Ibid.).

\section{ELR Operates as a Buffer Stock}

The key countercyclical stabilization feature is its buffer stock mechanism, where labor in the ELR program is the buffer stock that fluctuates with the cycle (Mitchell 1998). In recessions, workers who are laid-off from the private sector find jobs in the ELR program, expanding government spending counter-cyclically. Once the economy recovers, they are hired away from the public sector into better-paying private sector jobs, reducing public expenditure.

\section{ELR Stabilizes Wages and Prices}

As with any buffer stock program, ELR stabilizes the price of the buffer stock-in this case, wages at the bottom (Mosler 1997-98, Mitchell 1998). An ELR worker will be hired by a private employer at a premium above the ELR wage and, thus, the ELR wage becomes the 
effective minimum wage. Although it should not compete with wages in the private sector, some argue that it should be set at the living-wage level that establishes a minimum wagebenefit standard for the economy (Tcherneva 2006). To the extent that wages are a cost in every producible and reproducible commodity in the economy and the ELR program stabilizes them at the bottom, the program would also help stabilize prices (Forstater 1999a). Other price stabilization features include the countercyclical mechanism that alleviates both inflationary and deflationary pressures in the economy as a whole, as well as the program's supply-side effects. In contrast to income-support programs, ELR directly increases both the demand for workers and the supply of goods and services. That supply can be directed to satisfy the very needs of the previously unemployed and poor, thereby absorbing part of the ELR wage.

\section{ELR Spending Is Always at the Appropriate Level}

With pro-growth, pro-investment pump priming policies, economists never know exactly how much stimulus is needed to produce genuine full employment. Producing effective demand consistent with full employment is particularly difficult with such policies because the determinants of effective demand (investment, saving, and portfolio allocation) are highly subjective and not under the direct control of policy makers (Tcherneva 2011b). With ELR, however, government spending will be no more and no less than what is necessary to hire all who wish to work (Wray and Mitchell 2005).

\section{ELR Operates with Loose Labor Markets}

The program must be flexible enough to absorb new entrants in the ELR pool but also to let them go when they find private sector employment, without major disruptions to the public sector projects (Forstater 1999a). A careful program design will produce a database of such tasks that can be easily shelved when there is little demand for ELR work. But it will also permit some level of experimentation if there is an unexpected influx of workers into the ELR pool. Keynes's own view was that macroeconomic stability and full employment would be achieved by hiring the jobless directly into a long-term program for the socialization of investment, where a considerable amount of investment would be under public or semi-public auspices (Keynes [1936] 1964). This means that at any given time, the pool of public sector workers would be quite large. But should unemployment unexpectedly develop, the state would play the role of “entrepreneur in chief” to provide enough employment opportunities (Keynes 1981, 324). In the 
absence of a sizeable socialization of investment, however, the ELR program would serve essentially the same function of delivering macroeconomic stabilization and full employment through direct hiring into socially useful projects. Thus, some have compared the ELR program to a universal public service employment scheme (Harvey 2000).

\section{ELR Is Financially Sustainable over the Long Run in Sovereign Currency Nations}

ELR proposals are normally linked to the Post Keynesian modern money and functional finance literature, which argues that countries with freely floating nonconvertible currencies face no solvency problems or technical constraints in funding these programs in perpetuity (Mosler 1997-98, Wray 1998). More than that, ELR itself can serve as a benchmark for the value of such fiat currencies (Tcherneva 2006). Currency values are very complexly determined, but they essentially reflect what one can buy with the currency. Advocates argue that the ELR hourly wage pins down a basic conversion rate between labor and the currency. In other words, a \$10/hour ELR wage, for example, anchors the currency in labor power and sets the value of the dollar to be equal to six minutes of work. If the wage were doubled, then as a benchmark (recall ELR stabilizes all wages at the bottom), one dollar will exchange for three minutes of work or will erode in value by half. So when the emitter of the currency (the government) sets the exchange rate between the currency and the labor in the countercyclical buffer stock pool, it helps stabilize the value of its currency. Freely floating nonconvertible currencies today have no equivalent anchors. Finally, ELR advocates argue that in the absence of a solvency problem, the effects of government policy must be evaluated according to the principles of functional finance, namely by the program's real effects on the economy and not by its financial costs (Forstater 1999b).

\section{ELR Maintains and Enhances Human Capital}

Unlike cash transfers, this employment safety-net does not waste human potential by keeping the unemployed and poor members of society in idleness and misery. Instead, it mobilizes their manpower for the public good. Even the poorest and least educated individual has something to contribute to their community. ELR aims to find them decent work that provides both on-the-job training and other educational opportunities that prepare them for post-ELR work. 


\section{ELR Workers Perform Socially Useful Work}

ELR supplies public goods and services that the private sector generally fails to provide. There is no shortage of needs that require attention in any community, be it poor or of relative means. The job of policy makers is to carefully assess those needs and the available resources to adequately address them, as well as to improve upon current projects and implement others that may be deemed more beneficial.

\section{ELR Has Key Preventative Features over the Long Run}

Keynes recognized early, that it is one thing to maintain full employment over the long run through private and public employment schemes and an entirely different task to eliminate unemployment once it has developed in the absence of such programs (Keynes 1980: 316). In the latter case, the policy response is always too small and always too late and, without a plan for direct employment, unemployment always accelerates far too quickly. Furthermore, much greater policy intervention is needed to produce job growth through pump priming policies, which never garner sufficient support to generate anything close to true full employment.

\section{ELR Is an Institutional Vehicle to Achieve Other Socioeconomic Goals}

ELR can be used as a strategic tool for addressing pressing socioeconomic problems, beyond that of unemployment. Research on direct job creation has identified some potentially transformational effects on poor women and destitute communities of such programs, which will be discussed below (Tcherneva 2005; Tcherneva and Wray 2005a,b,c,d). Other scholars have advocated that ELR take the form of a Green New Deal or a Green Jobs Corps that launches a massive environmental renewal effort and public investment in green technology (Forstater 2004).

\section{WHAT WAS PLAN JEFES AND HOW WELL DID IT CONFORM TO THE ELR MODEL?}

Argentina was once considered the success story of neoliberal policies. Yet, after a decade and a half of stagnant growth and deteriorating socioeconomic conditions, in 2001 the Argentine economy plunged into its most severe crisis in history. The unemployment rate, which had been accelerating in the years prior to the financial crisis, peaked at 21.5 percent (under the 
conservative methodology of measuring unemployment) by May 2002 (Figure 1). The worsening living conditions prompted thousands of people to join peaceful protests that started on December 12, 2001, called "cacerolazo," organized by a small merchants association. From December 14-17, 2001, Frente Nacional Contra la Pobreza (FRENAPO), or the National Front Against Poverty - a broad coalition of groups of unemployed, progressive labor, human rights, and small business organizations_-organized a national campaign run exclusively by volunteers demanding from the government to implement a jobs program for the unemployed.

Figure 1 Unemployment rate in Argentina

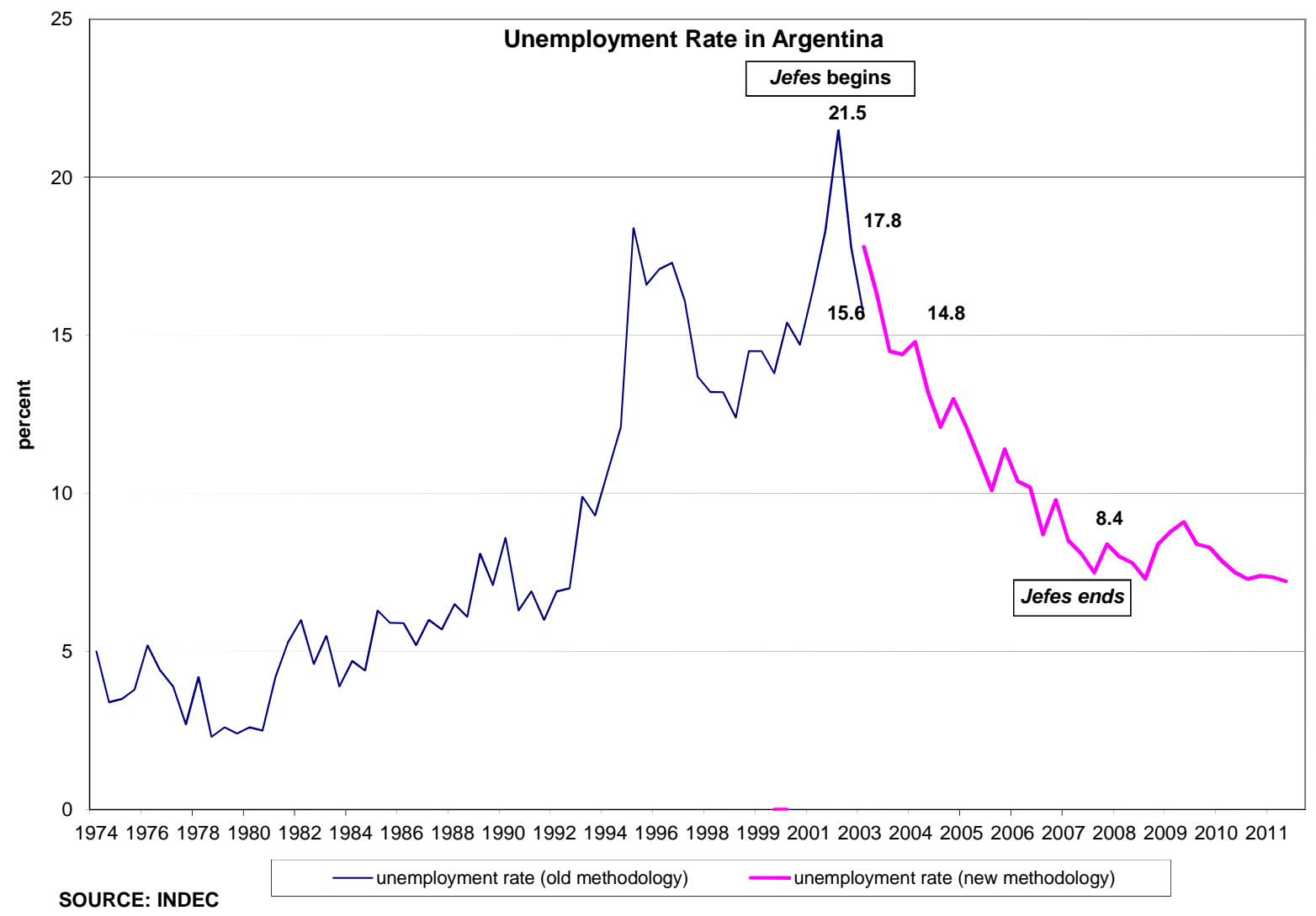

In a matter of two days, protests forced both the economic minister Cavallo and President De la Rua out of office. The first interim president Adolfo Rodríguez Saá, who held office for only one week, signed a key presidential order establishing a job creation program for unemployed heads of households called Plan Jefes de Hogar. The proposal had been put together by a team of economists at the Ministry of Labor, which was modeled after the ELR

${ }^{1}$ A form of protest where people take to the streets banging pots and pans, or "cacerolas." 
proposals developed in the US (Kostzer 2008). The following president, Eduardo Duhale, signed the emergency decree for the establishment of Plan Jefes into law. It became the primary program to deal with social dislocation in the aftermath of the currency board collapse.

Plan Jefes provided a payment of 150 pesos per month to a head of household for a minimum of 4 hours of daily work. Participants worked primarily in community projects and were directed to training programs, including finishing basic education. To be eligible, the household had to have children under age 18, persons with disabilities, or a pregnant woman. Households were generally limited to one participant in the Jefes program. The program's total spending peaked at 1 percent of GDP, with nearly 2 million participants. This is was equivalent to about 5 percent of the population and 13 percent of the labor force. ${ }^{2}$

Several evaluations of the program by the Ministry of Labor (MTEySS 2002, 2003, 2005) and the World Bank $(2002,2003)$ reported overwhelmingly positive results. What is of interest here is whether Plan Jefes performed in a manner suggested by ELR advocates.

\section{Did Jefes Offer an Infinitely Elastic Demand for Labor?}

Plan Jefes was clearly implemented as a depression solution, which is how direct employment schemes are traditionally used. Although it did not provide employment to all who needed it, it nevertheless took workers "as they are." Jobs were provided to heads of households (presumably male), but the intra-household decisions in the majority of cases designated the woman as the head of the household. By 2005, nearly $3 / 4$ of the participants who turned up for work were women (Figure 2). There were no skills means tests and men and women were offered employment into community projects irrespective of their past labor market experience, level of education, or skill.

\footnotetext{
${ }^{2}$ For details on the history of the program, see Kostzer (2008).
} 
Figure 2 Jefes beneficiaries by gender

Jefes Beneficiaries by Gender

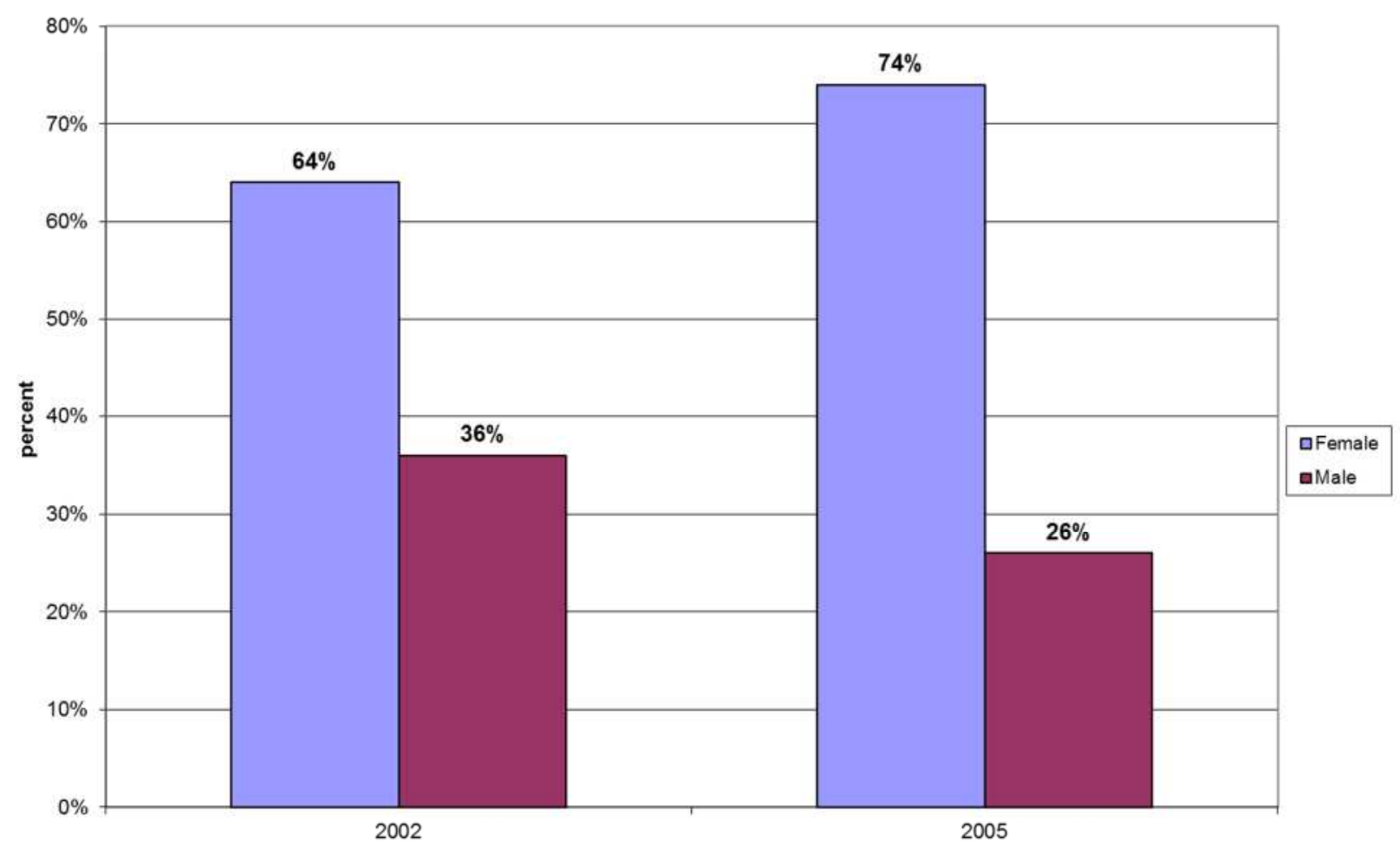

SOURCE: Ministry of Labor, Employment and Social Security, Argentina

\section{Did Jefes Hire Off of the Bottom?}

Data indicates that even though the program did not provide universal access to all of the unemployed the way the ELR is supposed to, it was nevertheless very well targeted (MTEySS 2002 , 2003). The vast majority of program participants came from the bottom quintile of the income distribution, had high school or lower education, and experienced long spells of unemployment or precarious employment in the informal economy. Thus, Plan Jefes, despite its primary focus on heads of households, ended up hiring from the bottom of the income distribution. Most conventional policies prime the pump to generate growth in the hopes of reducing unemployment to desired levels. In the case of Argentina, the government did not wait for the economy to recover to deal with the jobless problem. Direct hiring took place before growth returned and the unemployment rate fell precipitously as the economy recovered. In other words, unemployment was not left to be a lagging indicator and growth was largely a consequence of the pro-employment strategy. 


\section{Did Jefes Operate as a Buffer Stock?}

The Jefes payrolls ballooned quickly. The government had estimated that only 500,000 would show up for work, whereas, at its peak, Jefes had hired 2 million people. ${ }^{3}$ The size of the program had prompted policy makers to devise plans to phase it out and reform it. ${ }^{4}$ The presence of many poor and unskilled women in the program was particularly troubling to policy makers, who argued that their place was back in the home because they were largely "unemployable" (Decreto 1506/2004). The reform was a decisive step back for women because poor women, in particular, benefited greatly from the access to paid community work. But while Jefes was still in operation, payrolls gradually and steadily shrunk in a countercyclical fashion as soon as the economy recovered. This was precisely what the ELR proposal suggested would happen. It took less than a year to see these countercyclical effects. Almost 3/4 of the male beneficiaries took up construction and manufacturing private sector jobs, while female beneficiaries moved to the service sector. In 4.5 years, the Jefes payrolls fell by over 40 percent from their peak (Figure 3). This is quite an achievement, considering that most of these workers were some of the least educated and least skilled workers in the nation. There is no way of knowing how the program would have evolved, because it was hastily reformed as soon as payrolls declined considerably. Under the new reform, the remaining men from the Jefes program were given traditional unemployment insurance support and were enrolled in training and education programs that would help them transition to private sector employment. By contrast, the vast majority of Jefes women were moved to a conventional welfare program, which provided them with income support that varied with the number of children in the family, but which did not offer an employment opportunity (more below).

\footnotetext{
${ }^{3}$ This is an indication that open-ended job offers such as these will bring many previous discouraged individuals back into the labor force. Thus, any program design must account for the reactivation of those individuals who the official statistics failed to capture as unemployed.

${ }^{4}$ And indeed after about 4.5 years of operation, Jefes was gradually closed down.
} 
Figure 3 Number of Jefes beneficiaries over the years

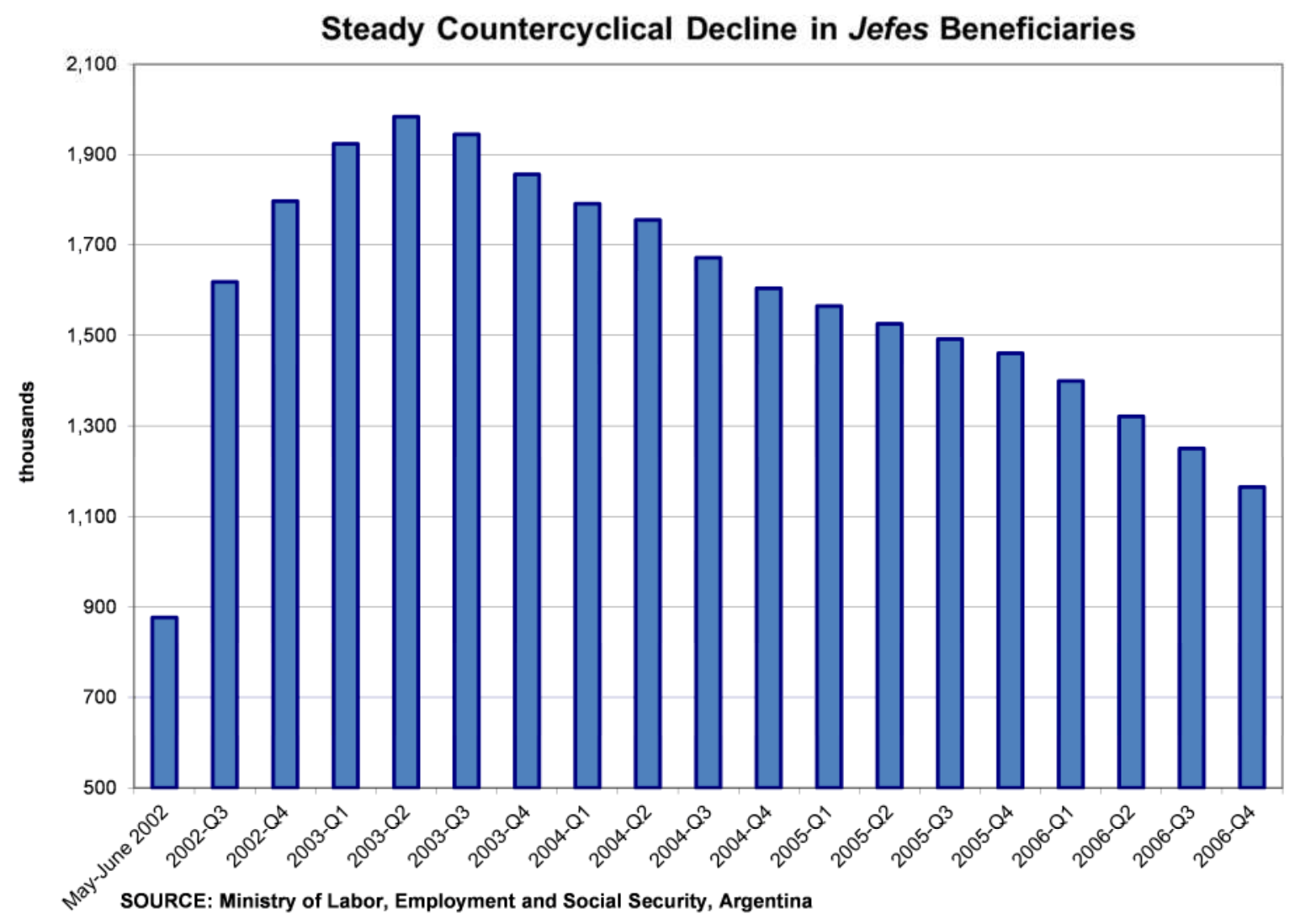

\section{Did Jefes Stabilize Wages and Prices?}

Although Argentina's consumer and producer prices suddenly increased with the devaluation of the peso, they quickly settled down and stabilized as the economy recovered. There was some renewed price pressure during the recovery which was largely associated with commodity price spikes and more expensive imports. Demand from Jefes itself, according to ministry officials, did not contribute to these pressures; indeed, these were mostly cost-push price increases. What Jefes did do however is establish a wage floor for those workers who transitioned from the Jefes program to private sector work. Almost 93 percent of Jefes workers who were hired into private firms were offered a wage above the Jefes wage, which indicates that ELR-type programs can indeed stabilize the price of the buffer stock, i.e., wages at the bottom (Figure 4). It must be stressed that to be sure of these effects, one needs to study a truly universal and long-term program. Importantly, however, the Jefes program helped formalize the informal sector. Beneficiaries were issued social security cards and once they moved to private employment, they were hired with traditional labor contracts that paid mandated benefits to all workers. 
Figure 4 Wages of Jefes beneficiaries once they moved to private sector employment

The Jefes Wage is the Effective Minimum Wage

\begin{tabular}{|l|c|}
\hline \multicolumn{2}{|c|}{ Distribution of beneficiaries who have been incorporated into the labor market according to } \\
salary received \\
\hline Salary received & Percent of beneficiaries \\
& \\
Less than 150 pesos & $6.8 \%$ \\
150 -- 349 pesos & $30.4 \%$ \\
$350--549$ pesos & $34.8 \%$ \\
550 -- 749 pesos & $17.7 \%$ \\
750 pesos and above & $10.3 \%$ \\
\hline TOTAL & $\mathbf{1 0 0 . 0} \%$ \\
\hline
\end{tabular}

Source: Ministry of Labor, Employment and Social Security, Argentina

\section{Was Jefes Spending Always at the Appropriate Level?}

Spending depended on the number of workers who enrolled in the program and the materials necessary once the projects were approved. It was "at the right level" in the sense that spending did not leak into private sector profits but instead was absorbed entirely by direct employment. In one other aspect, however, it was not "at the right level" because the program made no attempt to hire all who wanted to work. So while program spending was very small by any measure (less than 1 percent of GDP) considering the magnitude of the unemployment problem, it did not spend enough to hire all of the unemployed. Indeed workers who were not eligible for Jefes often led protests demanding direct employment from the government, as well. This led the public to increasingly associate (incorrectly) all Jefes beneficiaries with "violent" and "belligerent" workers, further eroding popular support for the program.

\section{Did Jefes Operate with Loose Labor Markets?}

The program was up and running in just a few months and quickly absorbed new entrants into the Jefes pool. It was also able to let go of Jefes workers once they found private sector employment without major disruptions to public sector projects. As indicated above, the Argentine government turned to the localities and municipalities to assess the basic needs and resources of the communities for more expedient implementation of the program. A level of experimentation clearly existed. The unemployed themselves initiated, organized, and staffed projects in their communities. While Keynes argued for the state to act as "entrepreneur in chief" (Keynes 1981, 324), in many cases in Argentina it was the poor and the unemployed 
themselves who showed that entrepreneurial initiative. They set up daycare centers, homeless shelters, and family attention centers for violence prevention where they were needed. The poor and their community groups petitioned the government for funding to help them set up food kitchens, subsistence farming, urban agriculture initiatives, and others. They also organized mass recycling efforts on a scale the public sector itself had not previously done.

\section{Was Jefes Financially Sustainable over the Long Run?}

Once Argentina abandoned the currency board, it had the financial freedom to employ domestic resources for the public purpose. Ability to pay in the domestic currency was no longer the problem. Though the budget itself was sustainable, the program itself was not expensive and it helped propel a sustainable recovery that ultimately brought the government budget into surplus.

\section{Did Jefes Have Key Preventative Features over the Long Run?}

As already mentioned because Jefes was phased out, it is not possible to assess how it would have performed as a long-term program for economic stabilization at full employment. However, in its short 4.5-year history, it became clear that Jefes brought key benefits to its participants. While it reduced indigency rates precipitously (by 25 percent only after 5 months of program operation), the decline in poverty rates was very small. This was largely due to the fact that the Jefes wage itself was below the poverty line. Nevertheless, poverty itself is a multidimensional problem, and it seems that the program nevertheless improved the lives of the poor in rather meaningful ways (see next section).

\section{Did Jefes Maintain and Enhance Human Capital?}

One of the most important benefits of Plan Jefes was that it provided an alternative to forced idleness. Beneficiary surveys indicate that, for the unemployed, the opportunity to earn income is not nearly as important as the opportunity to "do something" (Figure 5). This aspect of work - to be engaged, to contribute, to participate in the community — is often overlooked when discussing the problems of unemployment. Clearly, the loss of income and the inability to support oneself and one's dependents is a key problem that direct job creation programs can remedy, but they can also address many of the vile effects associated with forced idleness. 
Figure 5 Reasons why Jefes beneficiaries are satisfied with the program

Reasons Why You Are Satisfied With the Program

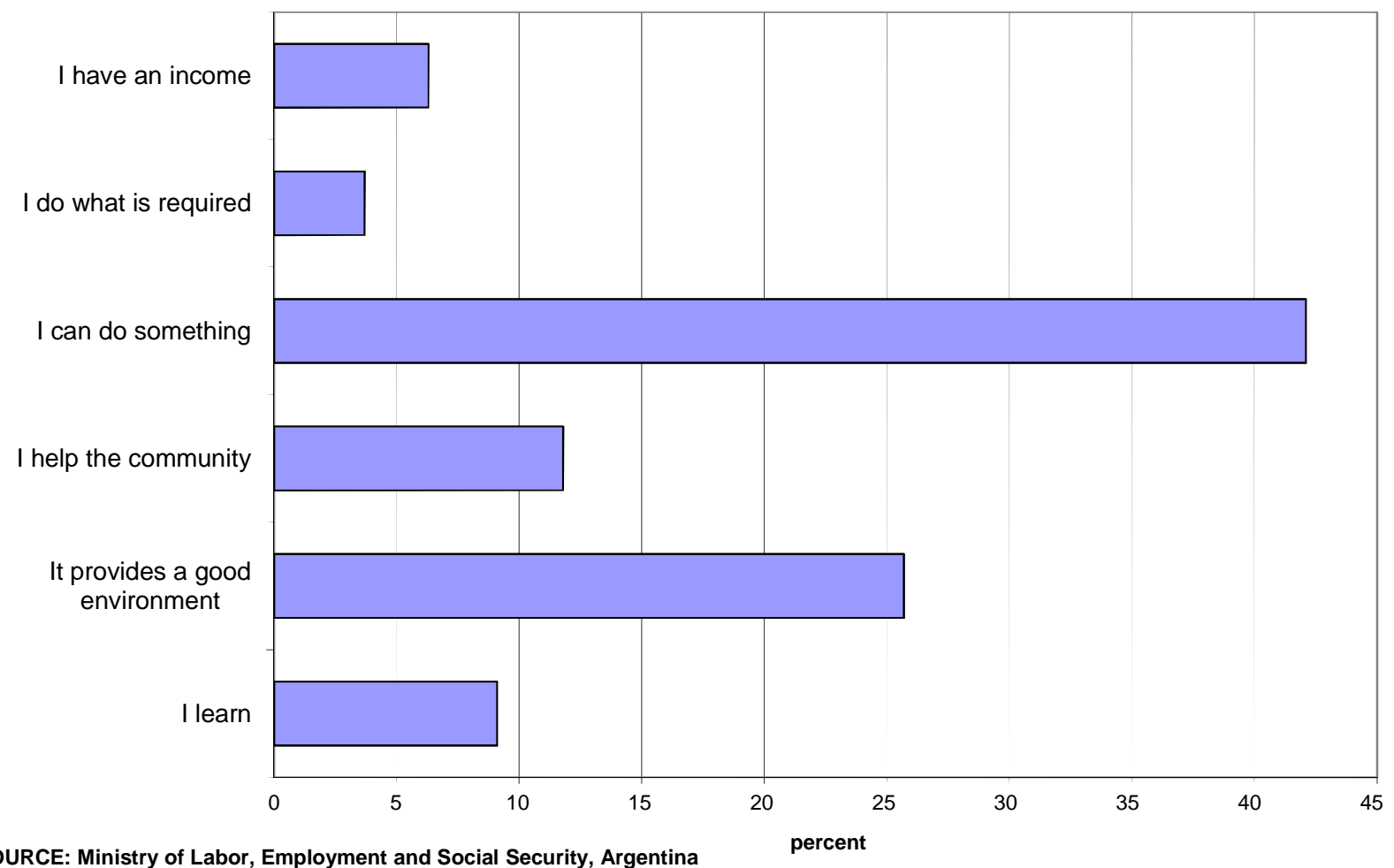

In addition, Jefes itself provided many supplementary programs that enhanced and improved human capital in other ways. These programs included child vaccination initiatives, health checkups, nutritional assistance, afterschool activities to curb school drop-out rates, and others.

\section{Did Jefes Workers Perform Socially Useful Work?}

The majority of Jefes projects performed useful community work. In some cases, the projects literally transformed communities (more below). Projects included improvements in the water supply, sewer systems, and pluvial networks. They made investments in health and educational infrastructure, improved hydraulic defenses, clay pits, municipal slaughter houses, recreational and tourist areas, and many others. In many instances, Jefes funds were used as seed money by the unemployed to launch their own businesses and micro-enterprises, some of which made toys from recyclable materials, others manufactured clothing for the domestic or export market, yet others set up carpentry and many other artisanal shops (for details, see Tcherneva 2005). Apart 
from the large-scale infrastructure initiatives, no less than 87 percent of Jefes projects were specifically targeted towards work in the community (MTEySS 2002, 2003).

\section{Was Jefes an Institutional Vehicle to Achieve Other Socioeconomic Goals?}

The final question that requires a more detailed consideration is how to harness the potentially transformative power of the ELR program. The Argentine experience indicates that, though not by design, Plan Jefes delivered important and unexpected benefits to the poor and to women in particular. This is the question we turned to next.

\section{ELR'S IMPACT ON POVERTY AND GENDER DISPARITY: LESSONS FROM JEFES}

What the macroeconomic data reports is that Jefes was able, in a relatively short period of time, to exhibit some of the stabilization features posited in the literature. Of course, without the ability to study an open-ended program which is open to all unemployed, one cannot be sure that it would perform as a genuine employer of last resort over the long run. What is missing from the macro-data, however, is the important narrative of program participants. Although the Ministry of Labor conducted two surveys of program participants (MTEySS 2003, 2005), survey evidence of program participants in most macro-stabilization programs that directly deal with unemployment and poverty is sorely missing. Indeed, without such survey evidence, the benefits to Jefes workers and the communities themselves would largely remain invisible. In the case of Argentina, we have at least three separate surveys-in addition to those conducted by the Labor Ministry (Ibid.) and the World Bank (2002, 2003)—-that I will examine here.

The work of Tcherneva (2005) and Tcherneva and Wray (2005a,b,c,d) is based on interviews of participants in several projects from two locations in Argentina-Cuidad Oculta, which was among the most destitute neighborhoods in Buenos Aires; and Almirante Brown, a downwardly mobile municipality in the outskirts of Buenos Aires. Pastoret and Tepepa's work (2006) presents narratives of poor women from Jefes projects in Lomas De Zamoras, a city that borders the Argentine capital. And finally, Garzon de la Roza (2006) has conducted extensive surveys of poor women from the city of Morón, also located in the Greater Buenos Aires metropolitan area. 
What the surveys demonstrate is that although the official poverty rate was not considerably reduced due to the low pay of the Jefes program, there were other tangible ways in which the program improved the lives of the poor. Moreover, it seems that paid employment served as an empowering institution for women. Indeed, there is reason to believe that such job guarantee programs could serve as institutional vehicles that would begin to redress some of the causes of gender disparity.

Interestingly, Jefes was not designed to deliver the benefits that women report in the surveys below. In fact, the program was initially called Plan Jefes de Hogar (i.e., program for male heads of households), and only after women enrolled in large numbers, it was renamed to Plan Jefes y Jefas de Hogar (plan for male and female heads of household). Although not by design, it did illustrate how public employment programs can advance women's issues.

As we consider these benefits, it is worth keeping in mind that the Jefes program was phased out after a few years of operation and replaced by two separate programs. One of them was a conventional unemployment insurance program for men, called Seguro de Capacitacion y Empleo, which also assisted them with training and education and helped them transition to private sector jobs. The other was a traditional welfare program called Plan Familias which gave a cash stipend to poor women with children, but without the opportunity to work in a community project in exchange. Policy makers insisted on reforming Jefes on the grounds that it artificially drew women into the workforce (women who were previously inactive and did not look for work) and that the vast majority of these women were "unemployable" because they were poor, uneducated, and had many children (Decreto 1506/2004). Those women, politicians argued, should not partake in Jefes, as they are already burdened by care responsibilities in the household and could not be expected to contribute to or benefit from the community project. The survey evidence that will be discussed below shows that this was not at all the case. Nevertheless, the reforms took place and were considered benevolent because it did not require poor women with many children to work for their cash assistance-it was now provided unconditionally. Note that Jefes offered the opportunity to work to any head of household. It did not require poor women to work. Nevertheless, in most cases, it was the family unit that had decided to designate the women the "head of the household" to take advantage of the job offer.

Tcherneva and Wray (2005d) report that every female participant they interviewed in Plan Jefes without exception wanted to work rather than receive a welfare check of equal amount. During the second evaluation of Plan Jefes, the Ministry of Labor also found that many 
women were disappointed to return to inactivity as a result of being moved into Plan Familias (MTEySS 2005). A third survey by Pastoret and Tepepa (2006) found that women who moved to Plan Familias, but whose Jefes community projects were not yet discontinued, kept going back to work, even though they were now exempt from the work requirement and no longer qualified for participation in Jefes.

\section{Gender Roles and Public Employment}

In many public sector projects, women tended to self-select in what are traditionally considered to be "female" work activities, but there were cases where women took on "male" jobs by setting up their own carpentry or shoe manufacturing shops, or by studying to be electricians or legal aids (Pastoret and Tepepa 2006). While many women working in Jefes still defined themselves within the traditional gender roles, they also considered their work to be a form of "social motherhood" (Garzón de la Roza 2006, 32). The primary benefit they reaped from the Jefes experience was a profound transformation in how they perceived their own self-worth (as stated above - this is an essential component of enhancing substantive freedoms). Their work in Jefes was a source of pride, which helped them acquire more power within the family. While women felt empowered from working outside the home, they did not completely escape their gender roles within the home. Often, their husbands disapproved of their employment in Jefes, which created a conflict within the household. However, eventually many men learned to "live with" the reality that their wives wanted to and did work outside the home (Ibid., 117). Had the job guarantee not been there, women would have had no recourse to resist the patriarchal attitudes of their spouses.

The gender literature has often emphasized that women, who dedicate many of their resources to children and family, need to begin to enhance their own outcomes, as well. Plan Jefes had notably allowed women to transcend the private-public divide and perceive themselves as more than just parents and domestic servants, whose sole responsibility was to raise children and maintain a household. Women reported that working and serving others was the best example they could give to their children and that they obtained many more valuable rewards from this experience than the monetary aspect, which was nevertheless very important to them. Women felt like they had "grown wings" (Garzón de la Roza 2006, 87).

The involvement in community work increased solidarity and transformed neighborhoods. Garzón de la Roza (2006) reports that residents found the district of Morón to 
have markedly changed during the five years of Jefes existence. This is consistent with Tcherneva and Wray (2005d) and Pastoret and Tepepa's (2006) findings of the transformative effects of Jefes projects on one of the most destitute regions of Buenos Aires: a region that was known for many years as Cuidad Oculta (the Hidden City), and that after 4 years of Jefes operation was renamed to Villa 15, as residents no longer believed to be outside the reach of public policy.

\section{How the ELR Delivers Benefits to All, But Especially to the Poor}

From the experience of poor women in the Jefes program, it seems plausible that an ELR program that is as well targeted as Jefes would deliver the greatest benefits to those who are truly at the bottom of the socioeconomic ladder. For example, Tcherneva (2005) reports that the beneficiaries' attitudes towards their Jefes experience depends in part on their level of education and previous work experience. Those men and women with higher levels of education and skills and previous work experience in the formal economy appreciated the opportunity to be engaged in some community service, but did not consider Jefes to be "real work," and were eager to return to their private sector jobs.

Consistent with Tcherneva and Wray’s (2005d) findings, Garzón de la Roza (2006) reports that some of the better educated individuals and those with previous work experience did not consider Jefes to be "real work," but that the poor and least educated women felt that Jefes had given them essential experience and benefits. Nonetheless, all participants agreed that only paid work enhances dignity and that receiving traditional income/welfare support brings a certain humiliation to the recipient. Because of the importance of work, all of the interviewed Jefes beneficiaries felt that all social assistance needed to be "earned with work" (Garzón de la Roza 2006, 111).

Plan Jefes was able to address not only the material but also the emotional destitution of people who had been trapped in forced inactivity for too long (Ibid.). Emotional benefits were derived when women found "coherency" and "completeness" in their life, when their existing knowledge was no longer "archived" in their memory but used to help the communities, when they could escape from demeaning informal sector domestic work and created a "home away from home" in the community center (Ibid., 104).

It was the poorest women who found empowerment and benefited the most from Jefes. Nonetheless, the major obstacles to their participation in the program were not their childcare 
responsibilities or poverty, but the social mores of policy makers regarding what was considered "productive" and "unproductive" work and who should be regarded as "employable" and "unemployable." These were the attitudes that drove the Jefes reform.

\section{A Note on Program Reform: Why Paid Work Is Superior to Welfare}

As noted above, in cases where Jefes projects were still operating, women continued to go to their places of work, but the government's effort to "encourage" them to leave Jefes was significant. This "marketing strategy" was partly motivated by the results of two pilot efforts to transfer Jefes workers to Plan Familias - one of the pilot programs was launched in the district of Ituzaingó, Bs.As., and the other in Santa Fé. The Inter-American Development Bank (IADB) argued that these pilot programs performed "acceptably" (IADB 2005, 29). In Ituzaingó 94 percent of the population that was considered unemployable was successfully persuaded to transfer to Plan Familias, but in Santa Fe less than 50 percent of the eligible population chose to leave Jefes (Ibid.). Because of these pilot results, it was recommended that the government expand its public relations efforts to explain the intended benefits of Familias to women participating in Jefes. In sum, paternalistic policies that presume to know what is better for the poor than the poor themselves drove the reform of Jefes, propelled by gender stereotypes about what type of work is productive and unproductive and which individuals are employable and unemployable.

While Plan Familias tried to supplement the cash transfer with various training, education, and empowerment workshops, women did not benefit from them as much as they did by having access to these through the Jefes program (which admittedly had too small a training and education component relative to needs). Nevertheless, the evidence indicates that poor women want to work and feel empowered from working in and for the community. An educational workshop may be able to teach them about their civil, social, and political rights, but Jefes allowed them to exercise them. Women can learn about empowerment in the classroom or they can be given tangible opportunities that empower. Workshops for violence prevention and information about shelters for the abused are all desirable and much needed, but Jefes had already begun to offer them. Furthermore, by actively participating in the provisioning of these services, women become not only "patients" of violence prevention, but "agents" of change. With Jefes, the burden of unpaid work associated with child rearing was not only reduced, but care was also explicitly recognized as a function of the larger community and not 
strictly of the individual family unit. This important aspect of the socialization of care has helped foster a stakeholder society and participatory democracy though public service.

The stipulation that only women are eligible for Plan Familias further reinforced the conservative view that women's work in Jefes was generally unproductive. The reform, therefore, called for sending them back to the home with a welfare check, providing them with information about remedial courses and training, but without the guarantee of a job available to them should they want one. This reform was essentially based on the old ideology that government policies must induce or nudge women to change their own behavior and character to become "employable" if they wanted private sector work. Women's roles as mothers and spouses were reinforced by this reform, while at the same time attempts were made to help their husbands to transition to private sector employment.

\section{Poor Women Want Pay, Not Handouts}

Poor mothers want to participate in mainstream society, to receive wages, and to contribute to private market and community production. At the same time, poor mothers feel the pressing need for mainstream society to recognize their care work and community work as useful. Women also understand that income alone does not empower. Social mores dictate that genuine empowerment comes from earned income, not charitable contributions. Although non-wage income entitlements to women attempt to recognize household work as socially-useful work deserving of financial support in a monetized society, they do not carry the same benefits women report from engaging in paid employment, nor do they help break the gender stereotypes of division of responsibilities within the household.

Public employment safety-nets such as the employer of last resort are institutions that put human needs first as they redefine "efficient" from what is "profitable" to what is "useful" (see, also, Archer 2003 on this distinction). They engage their participants directly in the goal of advancing the public purpose and are therefore programs that promote inclusion. Thus, when designing fiscal policy the inclusion/exclusion nexus matters.

Policy makers' claim that it is undesirable to activate women through these job guarantee programs (by "artificially" bringing them into the labor market) failed to consider what poor women actually want. Women often serve as a buffer to complement earning strategies of families during times of crisis. In terms of the power relationships within the household, women may be able do so because, during crises, their husbands may allow them to 
participate in work outside the home, but when family earnings are adequate, women are thrust into inactivity by social mores, husband attitudes, or simple lack of employment opportunity. The job guarantee by contrast recognizes the right of all men and women to participate in a universal employment program that redefines civic society. Men's resistance to women participation may be less if the job guarantee is accessible to all, but furthermore, the very existence of a guaranteed employment opportunity will provide the teeth in women's bite when they demand work outside of the home. Again, it is important to note that the job guarantee and the employer of last resort are not coercive programs; they offer income and the opportunity to work. Homemakers who prefer to stay at home will feel no obligation to join such a program and can enjoy the benefits of the universal child allowance which supplements the public employment strategy.

\section{Why It Is Important for the ELR to Offer Access to All}

The job guarantee must be a universal program, even if it can deliver key benefits especially to women. If it is not universal, it will create social antagonism and reactionary sentiment, as demonstrated by the Jefes experience. If Jefes were designed as a universal program, it would have likely produced more equitable distribution between male and female participants in the program. Additionally, because Jefes was not universal, unemployment in Argentina was not wiped out, even though it declined immediately and dramatically.

If equal access was granted to all, women would have likely suffered less stigmatization than they did. Individuals who participate in public employment would not be stigmatized as much as those receiving welfare. Although, it must be noted that because welfare recipients are often largely invisible, society does not always rally opposition to welfare programs-even if they are more expensive or less effective than public employment schemes. Thus, it is very important that the visible public output produced by women and men is both useful and needed, but is also adequately acknowledged as such.

A universal Jefes would have also produced a faster formalization of informal activity and a stronger countercyclical effect. Nevertheless, men still enter private sector employment in larger numbers than do women ${ }^{5}$ (MTEySS 2005), indicating various barriers to entry into private sector jobs (discrimination, lack of prior opportunities, or employment experience) or

\footnotetext{
${ }^{5}$ Although women comprised about 74 percent of Jefes participants in 2005, only 34 percent of all Jefes participants who found private sector employment after enrolling in the program were women (MTEySS 2005).
} 
simple self-selection, if women prefer the proximity to the home. Thus, the job guarantee must be accompanied with fair hiring laws, affirmative action, and other provisions. The job guarantee cannot correct all discrimination in hiring practices, but it could potentially ensure that private employers, hiring from the public sector pool, do so on the basis of skill and not on gender. Furthermore, the job guarantee itself can be designed in a way to increase the "employability" of women, but because it guarantees the job opportunity in the public sector, it also allows women to refuse private sector employment in sub-par conditions.

Finally, in Jefes, the products and earnings from public employment were not controlled by men. Women produced, distributed, and sold their own output. They kept portions of their earnings to reinvest in the co-op or micro-enterprise, or to spend on household and child needs. While women clearly believed to be empowered by the job opportunity, it is quite possible that such empowerment may emasculate their spouses engendering resentment towards working in the public sector. This is why universalization, not elimination, of the Jefes Plan would have been a better course of action. Men have less resistance to female employment when both genders have access to the same opportunity, even if men do not end up taking proportionate advantage of these opportunities. In the modern context, it is less likely to improve the employment practices of multinational corporations sufficiently quickly to allow women equal employment opportunities. Although such a goal is of utmost importance for more egalitarian labor market conditions, one step towards achieving it is by providing employment opportunities to men and women in the public sector. So long as these public sector jobs have a gender-informed design, they will be able to incorporate the care economy in the public sphere and help redefine the meaning of work away from strict market utility towards social usefulness. Such a re-conceptualization of work and of the public sector domain is necessary for implementing sustainable and gender-aware long-term policies for macroeconomic stabilization, full employment, and poverty alleviation. 


\section{CONCLUSION}

The literature on ELR tends to emphasize the important macroeconomic stabilization effects of the program. Importantly, this is among the very few policy proposals that secure and maintain as close an approximation to full employment as is practical over the long run. The latter objectives are, after all, the raison d'être for fiscal policy, as articulated by John Maynard Keynes. As we examine the merits of the ELR proposal, there is reason to believe that the program can address concerns beyond those of unemployment. Indeed, ELR can be a transformative policy tool that deals with pressing socioeconomic problems, such as poverty and gender disparity. ELR becomes not just a policy for full employment but an institution for change. 


\section{REFERENCES}

Archer, Margaret. 2003. "The Meaning of the Primacy of Labor over Capital." In Forum on the Meaning of the Priority of Labor. Vatican City, Vatican City State: The Pontifical Academy of Social Sciences.

Decreto $n^{\circ} 1506 / 04$ :

http://www.sigen.gov.ar/documentos_pdf/red_federal/decreto_1506_2004.pdf, accessed May 1, 2007.

Forstater, M. 1999a. "Full Employment and Economic Flexibility." Economic and Labour Relations Review 11 (0), Supplement: 69-88.

Forstater, M. 1999b. "Functional Finance and Full Employment: Lessons from Lerner for Today." Journal of Economic Issues 33 (2): 475-482.

Forstater, M. 2004. "Green Jobs: Addressing the Critical Issues Surrounding the Environment, Workplace and Employment." International Journal of Environment, Workplace and Employment 1 (1): 53-61.

Garzon de la Roza, G. 2006. "Continued Struggle for Survival: How Plan Jefes y Jefas Affected Poor Women's Lives in Greater Buenos Aires, 2002-2005.” Georgetown University Development Management and Policy Program Collection. http://hdl.handle.net/1961/4188, accessed February 15, 2012.

Harvey, P. 2000. "Direct Job Creation.” In A. Warner, M. Forstater, and S. M. Rosen (eds.), Commitment to Full Employment: Macroeconomics and Social Policy in Memory of William Vickrey. M.E. Sharpe, 35-54.

IADB. 2005. "Support for the Plan Familias Program, Argentina." Inter-American Development Bank Loan Proposal AR-L1006.

Kaboub, F. 2007. "Employment Guarantee Programs: A Survey of Theories and Policy Experiences," Working Paper 498, Annandale-on-Hudson, NY: The Levy Economics Institute (May).

Keynes, J.M. 1964[1936]. The General Theory of Employment, Interest, and Money, New York: Harcourt-Brace \& World, Inc.

1980. Activities 1940-46. Shaping the Post-War World: Employment and Commodities. Volume XXVII of Collected Works, D. Moggridge (ed.). London, UK: Macmillan.

1981. Activities 1922-29. The Return to Gold and Industrial Policy: Part II. Volume XIX of Collected Works, D. Moggridge (ed.). London, UK: Macmillan.

Kostzer, D. 2008. "Argentina: A Case Study on the Plan Jefes y Jefas de Hogar Desocupados, or the Employment Road to Economic Recovery." Working Paper No. 534. Annandaleon-Hudson, NY: Levy Economics Institute. 
Minsky, H.P. 1986. Stabilizing an Unstable Economy, New Haven, CT: Yale University Press.

Mitchell, W.F. 1998. "The Buffer Stock Employment Model and the NAIRU: The Path to Full Employment," Journal of Economic Issues, 32 (June): 547-556.

Mitchell, W.F. and Wray, L.R. (2005), 'In Defense of Employer of Last Resort: a response to Malcolm Sawyer,' Journal of Economic Issues, 39(1), 235-245.

Mosler, W. B. 1997-98. "Full Employment and Price Stability." Journal of Post Keynesian Economics, 20 (2): 167-182.

MTEySS. 2002. Impacto Macroeconómico Del Programa Jefas y Jefes De Hogar. Buenos Aires, Argentina: Ministerio de Trabajo, Empleo y Seguridad Social, Agosto.

. 2003. Plan Jefas y Jefes de Hogar Desocupados: Un año de gestión, Mayo 2002 Mayo 2003. Buenos Aires, Argentina: Ministerio de Trabajo, Empleo y Seguridad Social.

. 2005. "Segunda Evaluación del Programa Jefes de Hogar. Resultados de la Encuesta a beneficiaries." Buenos Aires, Argentina: Ministerio de Trabajo, Empleo y Seguridad Social.

Pastoret, C. and M. Tepepa. 2006. "Community Development and ELR: A Gender-Aware Perspective and the Jefes and Jefas Program in Argentina." In D. Papadimitriou (ed.), Employment Guarantee Policies: Theory and Practice. The Levy Economics Institute Conference Proceedings, presented at the 2006 Conference on the Employer of Last Resort, October 13-14.

Tcherneva, P. R. 2005. "The Art of Job Creation: Promises and Problems of the Argentinean Experience.” C-FEPS Special Report 05/03, Kansas City, MO: Center for Full Employment and Price Stability of the University of Missouri-Kansas City.

. 2006. "Universal Assurances in the Public Interest: Evaluating the Economic Viability of Basic Income and Job Guarantees." International Journal of Environment, Workplace, and Employment 2(1): 69-88.

. 2011a. "The Case for Labor Demand Targeting." Journal of Economic Issues 45(2): 401-409.

. 2011b. "On-the-spot Employment: Keynes's Approach to Full Employment and Economic Transformation." Review of Social Economy iFirst, July 2011 (print version forthcoming)

- 2012. "Employer of Last Resort." In J. King (ed.), Elgar Companion to Post Keynesian Economics, Northampton, MA: Edward Elgar, (forthcoming).

Tcherneva, P. R. and L. R. Wray. 2005a. "Common Goals - Different Solutions: Can Basic Income and Job Guarantees Deliver Their Own Promises?" Rutgers Journal of Law and Urban Policy 2(1): 125-166. 
. 2005b. "Employer of Last Resort: A Case Study of Argentina's Jefes Program." C-FEPS Working Paper No. 41, Kansas City, MO: Center for Full Employment and Price Stability of the University of Missouri-Kansas City.

. 2005c. "Is Argentina's Jefes de Hogar an Employer of Last Resort Program?" CFEPS Working Paper No. 43, Kansas City, MO: Center for Full Employment and Price Stability of the University of Missouri-Kansas City.

. 2005d. "Gender and the Job Guarantee: The Impact of Argentina's Jefes Program on Female Heads of Households." C-FEPS Working Paper No. 49, Kansas City, MO: Center for Full Employment and Price Stability of the University of Missouri-Kansas City.

World Bank. 2002. "Project Appraisal Document on a Proposed Loan in the Amount of US\$600 Million to the Argentine Republic for the Jefes De Hogar (Heads of Household) Program Project." World Bank Report No. 23710-AR. October 22.

World Bank. 2003. "Implementation Completion Report (SCL-43660) on a Loan in the Amount of US\$284 Million Equivalent to the Argentine Republic for a Third Social Protection Project." World Bank Report No. 26134-AR. June 30.

Wray, L. R. 1998. Understanding Modern Money: The Key to Full Employment and Price Stability. Cheltenham, U.K.: Edward Elgar. 